\title{
OS DESAFIOS DA DEFENSORIA PÚBLICA NA RESIGNIFICAÇÃO DOS ESPAÇOS PÚBLICOS
}

CHALLENGES OF PUBLIC DEFENDER'S OFFICE TO RESIGNIFY PUBLIC PLACES

Wilza Carla Folchini Barreiros

Especialista em Direito Ambiental e Urbanistico pela PUC/Minas. Defensora Pública Federal

wilza.barreiros@dpu.def.br

\section{RESUMO}

O artigo visa abordar a importância do planejamento urbano na redução da desigualdade social na medida em que focalize a justa e a igualitária distribuição do espaço público. Para além dos programas habitacionais já existentes o que se propóe são vias diversas de redemocratização do espaço público, como a utilização de imóveis públicos da União desocupados e regularizaçấo dos já ocupados, visto que estes normalmente estáo inseridos em ambientes que fomentam a inclusão social, efetivando, assim, a função social da propriedade. Neste contexto a Defensoria Pública tem relevante função, visto ser instituição forjada para dar voz aos excluídos, cabendo agir na reduçáo das desigualdades sociais e regionais, o fazendo na proporção que cobra a efetivação de políticas públicas de habitação e como legitimado na regularização fundiária de interesse social.

Palavras-chave: Redução da desigualdade social. Defensoria Pública. Ocupação do espaço público. Imóveis da União desocupados. Regularização fundiária.

\section{ABSTRACT}

The purpose of this paper is focus on the importance of urban planning to reduce social inequality as long as the process focus in a fair and equal public place distribution. Apart from existing housing programs what is being point are different ways to get democratization of public space, like to occupy empty public place and promote land regularization, because normally this building are inserted in a environment with a great potential of social inclusion, ensuring the social function of property. In this way Public Defender's 
Office has the relevant function, because one of institutional purpose is to give voice for the excluded people, acting to reduce social and regional inequality and the office does it when demand the realization of public politics in the area of housing and when take part in a land regularization.

Keywords: To reduce social inequality. Public Defender's Office. Occupation of public place. Empty public building. Land regularization

\section{SUMÁRIO}

INTRODUÇÃO 1. FORMAÇÃO DO ESPAÇO URBANO BRASILEIRO 2. PROGRAMAS HABITACIONAIS 3. O PAPEL DA DEFENSORIA PÚBLICA DA UNIÃO NA REDUÇÃO DAS DESIGUALADES SOCIAIS POR MEIO DA EFETIVAÇÃO DO DIREITO À MORADIA 3.1 Imóveis da Uniâo Desocupados 3.2 Regularização Fundiária de Imóveis da União. CONSIDERAÇÕES FINAIS.

\section{INTRODUÇÁO}

O crescente fosso social brasileiro, que conduz a forma de vida distinta entre ricos e pobres, corroendo a solidariedade e o senso de comunidade indispensáveis a cidadania democrática, tem no processo de democratização dos espaços públicos vital importância para reversáo do quadro posto.

A sociedade e suas instituição são chamadas a tomar lugar no processo de urbanificação, exigindo e velando pela ocupação dos espaços públicos de forma igualitária como forma de redução da desigualdade social. A Defensoria Pública, expressão e instrumento do regime democrático, tem especial relevo na democratização dos espaços públicos, vez que lhe cabe dar voz aos vulneráveis, excluídos do espaço público.

Inúmeras são as possibilidades de agir da Defensoria Pública para efetivar a função que lhe é atribuída constitucionalmente, todavia, neste artigo iremos nos ater a redução das 
desigualdades por meio da garantia do direito social à moradia e efetivação da função social da propriedade, mais especificamente a atuação da Defensoria Pública da União frente a imóveis públicos desocupados ou ocupados irregularmente pertencentes à Uniáo.

Para tal, se mostra necessário um breve introito da história das ocupaçóes no Brasil e dos programas de habitaçáo desenvolvidos por diversos governos, a fim de contextualizar a origem dos nossos problemas de habitação e as soluçôes dadas pela administração pública.

A partir da análise do passado é que se olha para o futuro, despontando que as soluçôes para contenção e redução da desigualdade vão além da redistribuição de renda, nesse cenário não se pode minimizar o papel da Defensoria Pública, importante instrumento de dignificação, de inclusão e de reconstrução do sentimento de pertencimento social.

\section{FORMAÇÁO DO ESPAÇO URBANO BRASILEIRO}

As ocupaçôes clandestinas e informais nas cidades, atualmente designados núcleos urbanos informais ${ }^{1}$, permeiam a construçấo do ambiente urbano brasileiro desde a constituição do império. A exclusão social urbana que impede a aquisição de moradia por grande parcela da população, segregando, periferizando, tem seu introito na Lei $n^{\circ} 601 / 1850$, a chamada 'Lei de Terras', que proibiu a aquisição de terras devolutas por título diverso que a compra, legitimando a posse dos que até então possuíssem terras cultivadas e nela fixassem sua moradia habitual.

Posteriormente, com a abolição da escravatura em 1888, um grande afluxo de ex-escravos migrou para os centros urbanos, esta populaçáo encontrou cidades despreparadas para recebe-los. Nos dizeres de Duane Brasil Costa e Uly Castro de Azevedo " $\mathrm{E}$ a partir da obtençấo dessas baixas remuneraçóes que o (a) escravo (a) consegue um lugar para morar, em bairros afastados do centro, ou seja nas periferias." ${ }^{2}$

A cidades brasileiras cresceram de forma desordenadas, sem política urbana e habitacional capaz de garantir moradia a parcela significativa da população, ao contrário, o processo de urbanização da população foi marcado pela exclusão social dos espaços públicos.

A nova classe de trabalhadores, agora assalariados, formada por escravos libertos e posteriormente imigrantes europeus, viu-se a margem da disponibilidade imobiliária, já que o alto valor dos alugueis eram impraticáveis diante míseros salários que recebiam. As moradias coletivas, conhecidas como cortiços, surgem como resposta à crise de moradia do fim do século XIX.

A partir da segunda metade do século XX, com a industrializaçáo das cidades brasileiras,

Artigo 11, II da Lei n. 13.465 de 11 de julho de 2017

2 COSTA, Duane Brasil e AZEVEDO, Uly Castro de. Das Senzalas às Favelas: Por onde vive a populaçáo negra brasileira. 2016 
o processo de urbanização brasileira entrou em acelerado crescimento. Esclarece Milton Santos sobre o que se entende por industrialização:

O termo industrialização não pode ser tomado, aqui, em seu sentido
estrito, isto é, como criaçấo de atividades industriais nos lugares, mas
em sua mais ampla significação, como processo social complexo, que
tanto inclui a formação de um mercado nacional, quanto os esforços
de equipamento do território para torna-lo integrado, como a expan-
são do consumeo em formas diversas, o impulsiona a vida de relaçóes
(leia-se terciarização) e ativa o próprio processo de urbanizaçáa."”’

Segundo dados do IBGE a população urbana brasileira na década de 40 era de 31,24\%, em 1970 a população urbana já supera a rural, formando um contingente de 55,92\%, em 2010 a população urbana atingiu o percentual de $84,36 \%{ }^{4}$.

O crescimento das cidades redundou no processo de expansão do território urbano dos municípios, criando periferias e afastando cada vez mais a população de baixo poder aquisitivo dos centros em que são ofertados serviços, empregos, oportunidades econômicas e culturais, normalmente território das classes média e alta, confinando-os em áreas sem infraestrutura, sem equipamentos públicos ou espaços comerciais, aumentando o já grave problema ambiental.

Atualmente a especulação imobiliária é um dos grandes responsáveis pelo processo de periferização, sendo que gradativamente, com a implantação de equipamentos urbanos e comunitários, as periferias passam a ser cobiçadas pela classe média e porque não dizer pela alta, gerando continuo processo de expulsão e expansão urbana, esta marcada pela criação de assentamentos informais.

\section{PROGRAMAS HABITACIONAIS}

A primeira intervenção direta do Estado no setor de habitação ocorreu com a edição do Decreto 1.749, de 28 de junho de 1937, que passou a autorizar aos Institutos e Caixas de Aposentadoria e Pensóes o emprego de seus saldos no financiamento para aquisição de prédios para moradia dos seus associados.

Com o intuito inicial de enfrentar os problemas de habitação da população de baixa renda o Governo Dutra cria a Fundação Casa Popular -FCP5 . Logo veio a percepção de que não bastava produzir moradias, indispensável o fomento de infraestrutura urbana. Assim, quatro meses após a criação, a Fundação Casa Popular teve suas frentes de atuaçóes am-

3 SANTOS, Milton. A Urbanizaçáo Brasileira, 2018, P. 30

4 INSTITUTO BRASILEIRO DE GEOGRAFIA E ESTATÍSTICA - IBGE. Séries Históricas e Estatísticas. Taxa de Urbanizaçáo. Disponível em: https://seriesestatisticas.ibge.gov.br/series. aspx?vcodigo $=$ POP122.

5 Decreto-Lei n. 9.218 de $1^{\circ}$ de maio de 1946. 
pliadas ${ }^{6}$. O objetivo foi ambicioso e não conseguiu avançar como imaginado na criação de moradias. ${ }^{7}$

Diante da grave crise no setor habitacional no país foi criado, durante o governo militar, o programa federal de habitaçấo por meio da Lei n. 4.380 de 21/8/1964, que institui o Sistema Financeiro da Habitaçáo (SFH) cuja vértice era facilitar e promover a construção e a aquisição da casa própria, especialmente pelas classes de menor renda da população. Constituiu-se também o Banco Nacional de Habitação (BNH), instituição financeira especializada em financiamento habitacional.

A criação do $\mathrm{BNH}$ foi fruto da convergência de interesses empresariais ligados a construçấo civil e o interesse em dinamizar a economia pelo governo, que com tal política alavancou a criação de empregos. A concessão de crédito tinha como fontes recursos pró-

\footnotetext{
6 Decreto-Lei n. 9.777 de 6 de setembro de 1946
}

Art. 1 A Fundação da Casa Popular (FCP), criada e regida pelo Decreto-lei no 9.218, de 1 de Maio de 1946, para que atinja as suas finalidades, incumbe:

I - proporcionar a brasileiros, e a estrangeiros, com mais de dez anos de residência no país, ou com mais de cinco anos quando tenham filhos brasileiros, a aquisição, ou construção, de moradia própria, na zona urbana ou rural;

II - financiar, na zona rural, a construção, reparação, ou melhoramento, de habitaçóes para os trabalhadores, de arquitetura simples e de baixo custo, mas que atendam aos requisitos mínimos de higiene e confôrto, bem como suprimento de energia elétrica ;

III - financiar as construçôes, de iniciativa, ou sob a responsabilidade de Prefeituras Municipais, emprêsas industriais ou comerciais, e outras instituições, de residências de tipo popular, destinadas à venda, a baixo custo, ou à locação, a trabalhadores, sem objetivo de lucro;

IV - financiar obras urbanísticas, de abastecimento dágua, esgôtos, suprimento de energia elétrica, assistência social, e outras que visem a melhoria das condiçôes de vida e bem-estar das classes trabalhadoras, de preferência nos municípios de orçamentos reduzidos, sob a garantia de taxas ou contribuiçóes especiais, que para isso forem criadas;

$\mathrm{V}$ - estudar e classificar os tipos de habitaçôes, denominadas - populares - tendo em vista as tendências arquitetônicas, hábitos de vida, condiçôes climáticas e higiênicas, recursos de material e mão de obra das principais regiốes o país, bem como o nível médio, econômico ou na escala de riqueza do trabalhador da regiáo:

VI - proceder a estudos e pesquisas de métodos. e processos, que visem o barateamento da construçáo, quer isolada, quer em série, de habitaçôes de tipo popular, a fim de adotá-los e recomendá-los;

VII - preparar normas, ou cadernos de encargos, de acôrdo com o resultado dêsses estudos, para o estabelecimento das condiçôes básicas a que devem satisfazer os planos a serem atendidos pela FCP, tendo em vista, especialmente, a máxima ampliação possível da área social de seus benefícios ;

VIII - financiar as indústrias de materiais de construção, quando, por deficiência do produto no mercado. se tornar indispensável o estimulo do crédito, para o seu desenvolvimento ou aperfeiçoamento, em atençáo aos planos ou programas de realizaçóes da

IX - estudar, projetar ou organizar planos de construção, de habitaçôes do tipo popular, a serem executadas diretamente pela FCP ou mediante contrato com terceiros;

$\mathrm{X}$ - cooperar com as Prefeituras dos pequenos municípios, que não disponham de pessoal técnico habilitado. quando de todo indispensável, e na medida dos recursos disponíveis da FCP;

$\mathrm{XI}$ - realizar tôdas as operaçóes que digam respeito à melhor execução das suas finalidades. dentro das atribuiçóes e competência que forem conferidas pela lei.

7 SOUZA, Leda Maria. Análise Comparativa Das Políticas Habitacionais Nos Governos Fernando Henrique Cardoso E Luiz Inácio Lula da Silva, 2005 
prios, cuja capitalização advinha principalmente da caderneta de poupança e do Fundo de Garantia por Tempo de Serviço (FGTS).

Apesar do objetivo do SFH de fomentar a aquisição de casa própria pela população hipossuficiente economicamente por meio da instituição financeira criada para tal, do total de 4,5 milhóes de financiamentos habitacionais concedidos de 1970 até 1986 (ano de extinção do banco) apenas $30 \%$ foram destinados a população de menor poder aquisitivo ${ }^{8}$.

As sucessivas crises econômicas enfrentadas pelo país, com desestabilização da moeda nacional, hiperinflação, levaram a redução da participação do Estado no financiamento habitacional, o que culminou em uma maior participação do capital privado no mercado imobiliário.

Registra-se que os recurso da poupança no financiamento imobiliário, grande promotor da expansão do crédito imobiliário, restaram reduzidos a partir da Resolução no 2458 do Conselho Monetário Nacional de 18/12/1997. A par desta mudança Mariana Fix descreve com maestria o momento vivenciado no Brasil:

A estabilização monetária com o Plano Real, lançado em 1994, combinou-se a esse quadro produzindo algumas modificaçóes. A partir de então, os planos de autofinanciamento permitiram que os segmentos de renda média e média baixa financiassem com recursos próprios o boom da produção habitacional de mercado, particularmente por meio de cooperativas habitacionais organizadas por empresas de assessoria técnica. ${ }^{?}$

A partir da década de noventa novas programas habitacionais foram criados, valendo citar o Programa de Arrendamento Residencial (PAR) e o Programa de Subsídio à Habitação de Interesse Social (PSH).

O PSH consistia no leilão pelo Estado de subsídio por regiōes, bancos podiam adquiri-los para, em parceria com os Municípios, construir unidades de habitação.

O PAR era voltado para a população cuja faixa salarial ia de 3 a 6 salários-mínimos, constituindo em um sistema de arrendamento em que o arrendatário, após quitação de todas as parcelas, tinha a opçáo de adquirir o imóvel.

É de aqui se fazer um parêntese para registrar que inúmeras cláusulas contratuais do PAR foram declaradas abusivas pelo Poder Judiciário, dentre elas a que previa que o valor residual integralmente embutido nas prestaçóes mensais da avença em caso de resoluçáo do contrato - em razão da opção do arrendatário em devolver o imóvel ao fim do prazo estipulado, ou de sua desistência ou, ainda, por ter descumprido quaisquer das cláusulas contratuais - não seria devolvido ao arrendatário em sua integralidade ${ }^{10}$.

8 ROLNIK, Raquel. Guerra dos Lugares: A colonizaçāo da terra e da moradia na era das finanças, 2015, p. 284

9 FIX, Mariana. Financeirizaçáo e transformaçóes recentes no circuito imobiliário no Brasil, 2011, p.120.

10 RECIFE. Tribunal Federal da 5a Região, ACP 2004.84.00.008808-7/RN, Relator Desembargador Federal Emiliano Zapata Leitão, DJe 16/09/2010. 
$\mathrm{Na}$ fase inicial do governo petista a política habitacional baseou-se no Projeto Moradia, elaborado pelo Instituto Cidadania. E para gerir a política urbana foi criado o Ministério das Cidades, a quem foi dada a incumbência de levar o mercado privado, antes concentrado em fornecer moradia as classes de mais alta renda, as classes de renda abaixo de 5 salários mínimos.

No início do século vinte tanto o crédito habitacional como a produção de unidades estavam em franco crescimento, euforia que restou abalada pela crise financeira de 2008, ano em que as empresas do setor imobiliário brasileiro estavam preparadas para lançar 200 mil unidades. Neste momento o setor imobiliário, atingido pela crise, passou a pressionar o governo para que este implementasse políticas habitacionais, consistente em concessão de subsídio direto ao comprador, o que viabilizaria a aquisição das unidades habitacionais que estavam prontas para entrar no mercado. Assim nasceu o Programa Minha Casa Minha Vida, que como afirma Raquel Rolnik "De pacote de salvamento de incorporadoras financeirizadas, o MCMV transformou-se na política habitacional do país." 11

O Programa Minha Casa Minha Vida vem sofrendo com o processo de estagnaçáo econômica e a atual política social do país, nem de longe lembra a promessa de pujança de seu início. Diante da atual crise dos programas habitacionais, que focam exclusivamente na edificação de complexos urbanos, outros instrumentos devem ser pensados e explorados pelo Estado.

\section{O PAPEL DA DEFENSORIA PÚBLICA DA UNIÁO NA REDUÇÁO DAS DESIGUALADES SOCIAIS POR MEIO DA EFETIVAÇÁO DO DIREITO À MORADIA}

O Programa Minha Casa Minha Vida - PMCMV -, assim como os programas anteriores, não tem conseguido dar a resposta adequada ao problema habitacional, seja pela insuficiência numérica das construções, por encurralar nas periferias as famílias que aderem ao plano, pela baixa qualidade das construções, pelas inúmeras reclamações sobre a forma de escolha dos candidatos, pela situação de abandono dos conjuntos habitacionais que frequentemente estão envolvidos em episódios de violência ou, ainda, pela impossibilidade dos moradores de arcar com custos de despesas que não estavam habituados, tais como condomínio, água e luz.

A baixa qualidade das construçóes, cobrança ilegais ou mesmo vícios no contrato tem levado a Defensoria Pública da União a ajuizar inúmeras ações civis públicas envolvendo o $\mathrm{MCMV}^{12}$.

11 ROLNIK, Raquel. Guerra dos Lugares: A colonizaçáo da terra e da moradia na era das finanças. 2015, p 309

12 Em Belo Horizonte/MG os residenciais Figueiras (Açáo Civil Pública n. 001796110201540113800, 5a Vara Federal de Belo Horizonte/MG), Hibisco (Ação Civil Pública n. 180165820154013800, 16a Vara Federal de Belo Horizonte/MG), Canários (Ação Civil Pública n. 180157320154013800, 12a Vara Federal de Belo Horizonte/MG) e Recanto do Beija-flor (Ação Civil Pública n. 179637720154013800, 12a Vara Federal de Belo Horizonte/MG) foram entregues sem piso. Já em São Luís/MA aos sorteados do programa para formalizar a aquisição das unidades habitacionais correspondentes aos Residenciais Pitangueiras e São José passou-se a exigir pagamento ilegal de imposto sobre transferência inter vivo (Ação Civil Pública 41170-85.2013.4.01.3700, 
Portanto, outras alternativas devem ser consideras, como a moradia subsidiada, o auxílio -aluguel, a destinação à habitação social de imóveis públicos desocupados e a facilitação da regularização destes imóveis irregularmente ocupados.

Ainda, as políticas de habitação devem ser pautadas na concretização do objetivo republicado de redução das desigualdades sociais. A urbanificação é importante instrumento para a consecução deste objetivo na medida em que se paute na ocupaçáo dos espaços públicos de forma igualitária, permitindo o acesso a todos os cidadãos aos equipamentos urbanos e comunitários - hoje implantados com a contribuiçáo de todos e usufruídos por alguns -, com a inserção da população vulnerável no espaço em que há disponibilidades econômicas e culturais, ocupados, em geral, pelas classes média e alta.

Neste contexto a Defensoria Pública, como instrumento do Estado Democrático de Direito, tem o dever de proteger e promover os direitos humanos dos grupos socialmente vulneráveis e, como tal, obriga-se a participar da efetivação de novas políticas de moradia que visem a redução das desigualdades sociais.

Dentre as inúmeras formas e instrumentos capazes de alcançar o objetivo republicano, ficaremos aqui adstritos a destinação para fins de moradia dos imóveis públicos desocupados e regularização fundiária dos imóveis públicos ocupados pela população de baixa renda, situaçôes em que a Defensoria Pública se constitui em importante ator.

\subsection{Imóveis da Uniáo Desocupados}

De acordo com a Secretaria de Patrimônio da União existem atualmente 179 imóveis públicos desocupados, todavia, sabe-se que o número é muito maior do que o informado em razão da precariedade dos dados coletados ${ }^{13}$. O Ministro do TCU Vital do Rêgo Filho cita em acórdão a existência de 18 mil imóveis da União Federal desocupados ${ }^{14}$.

Dentre os imóveis da União ditos desocupados muito são objeto de ocupações irregulares ou potenciais imóveis capazes de garantir o acesso a moradia da população de baixa renda.

Por sua vez, cabe o registro de que a função social da propriedade, de aspecto impulsivo e de limite ${ }^{15}$, compreende não somente os imóveis privados, mas também os públicos. A

6a Vara Federal de São Luiz/MA). Em Salvador a Defensoria Pública da União ajuizou a Ação Civil Pública 0030506-65.2012.4.01.3300 (16 ${ }^{\text {a }}$ Vara Federal de Salvador) visando sanar irregularidades contratuais.

13 BRASIL. Ministério do Planejamento, Desenvolvimento e Gestâo. Nota à Imprensa sobre Imóveis da Uniáo. Disponível em: http://www.planejamento.gov.br/noticias/nota-a-imprensa-7, publicado em 02/05/2018. Acesso em: 31 out. 2018.

14 BRASIL, Tribunal de Contas da União, Processo TC 025.715/2017-8, Acórdão 1273/2018, Relator Ministro Vital do Rêgo, Julgado em 06/06/2018

15 Ludovico Barassi, citado por Guilherme José Purvin de Figueiredo (A Propriedade no Direito Ambiental, 2008, p. 95), esclarece a funçáo social da propriedade em "Dois aspectos da funçáo social da propriedade: o de funçáo impulsiva, voltado em especial à propriedade dos bens de produção e à ordem econômica, em que se busca um rendimento ótimo dos bens econômicos; e a funçáo limite, de caráter mais geral, com características de intervenção limitadora do exercício da autonomia do proprietário, a fim de que se alcance maior fecundidade na gestão dos bens." 
ideia de função social forjada no final do século XIX - a partir da teoria de Leon Duguit, da doutrina social da Igreja Católica e das Constituiçóes de Weimar e do México, além das ideias socialistas -, com inúmeras depuraçôes desde entấo, chegou a contemporaneidade como elemento indissociável da propriedade. Assim sendo, a proteção do direito de propriedade depende de ela estar desempenhando sua função social, preceito previsto em nossa Lei Maior (artigos 5, XXIII, 170, III, 182, $\$ 2^{\circ}, 184,186$ ).

No que concerne a propriedade urbana estabelece o artigo $182, \$ 2^{\circ}$ da Constituição da República que esta "cumpre sua função social quando atende às exigências fundamentais de ordenação da cidade expressas no plano diretor.”

O Estatuto das Cidades (Lei n. 10.257/01) completa que "cumpre sua função social quando atende às exigências fundamentais de ordenação da cidade expressas no plano diretor, assegurando o atendimento das necessidades dos cidadãos quanto à qualidade de vida, à justiça social e ao desenvolvimento das atividades econômicas, respeitadas as diretrizes previstas no art. $2^{\circ}$ desta Lei."

Nessa linha os bens públicos estão subordinados ao interesse público e a função social, deixando de cumprir sua função socioambiental o imóvel perde seu título justificativo e, consequentemente, as garantias judiciais e extrajudiciais de proteção da posse.

Assim, a Uniẫo tem um conjunto patrimonial subutilizado - não cumprindo sua função social - que poderia servir para garantir moradia a um enorme contingente populacional, em sua grande maioria localizados em áreas providas de equipamento público, que demandariam obras menores, com custos inferiores, que as dispendidas com os programas habitacionais. A utilização deste patrimônio é meio promotor da igualdade social ao garantir acesso a parcela da população economicamente desprovida a serviços e possibilidades - melhores empregos, educação, lazer etc -, permitindo a ressignificação dos espaços públicos que passa a ser de todos e não mais de poucos privilegiados. Ainda, a utilização destes espaços abandonados é uma ação ambientalmente sustentável.

Neste contexto se vê a essencialidade do papel da Defensoria Pública da União que pode ser a ponte para o processo de dignificar, dando voz àqueles que o poder público insiste em não escutar. Para além da defesa dos cidadãos vulneráveis submetidos a precária e irregular situação habitacional, a Defensoria Pública é importante agente de inclusão e pacificaçáo social, uma vez que o local de habitaçáo é determinante no relacionamento entre os concidadãos e a diversidade do ambiente urbano possibilita não só o aceitar mais o identificar-se com o outro.

A atuação da Defensoria Pública não se dá apenas como interlocutor entre os movimentos sociais ligados a moradia e o poder público na promoção de políticas públicas habitacionais, cabendo a instituição abrir caminhos para que a população excluída participe das escolhas do destino da cidade.

Importante locus na Defensoria Pública da União para discutir e fomentar a habitação dos excluídos se deu com a criaçáo da função de Defensor Regional de Direitos Humanos, incumbido, dentre outras atribuições, de promover a defesa coletiva de direitos e interesse de grupos integrados potencialmente por indivíduos socialmente vulneráveis. 
Vale aqui citar a emblemática atuação da Defensoria Pública no que concerne a realocação das famílias atingidas pelo desabamento do Edifício Wilton Paes de Almeida, localizado no Largo Paissandu, na cidade de São Paulo/SP. O imóvel, pertencente a União Federal, rui, após incêndio, na madrugada do dia $1^{\circ}$ de maio de 2018, deixando aproximadamente 200 famílias desabrigadas, além de sete vítimas fatais. ${ }^{16}$

Após a tragédia a maior parte das famílias, incluindo idosos e menores, permaneceram acampados nas calçadas do Largo do Paissandu. A Defensoria Pública da Uniâo, em parceria com a Defensoria Pública do Estado de Sáo Paulo, passou a atuar em defesa das vítimas, após inúmeras reuniōes com autoridades públicas e movimentos sociais visando garantir o direito à moradia ${ }^{17}$, não restou outra alternativa senão ajuizar Ação Civil Públi$\mathrm{Ca}^{18}$, em que postulou, dentre outros, que a realocação das famílias fosse feita em imóveis que constem em listas como desocupados - houve a indicação de três prédios -, localizados a um raio de aproximadamente 300 metros do local em que estava situado o Edifício Wilton Paes de Almeida - região central de São Paulo.

É de se dizer que a inclusão social por meio da garantia de moradia digna, no caso, com a ocupaçấo legal de imóveis públicos não utilizados, é tarefa que demanda interdisciplinaridade, não basta o conhecimento jurídico do Defensor Público, é preciso assessoramento de engenheiros, urbanistas, além da direta parceria com os movimentos sociais. Náo basta que o imóvel esteja desocupado, deve estar apto a garantir a inserçấo plena das pessoas à cidade, assegurar adequado nível de habitabilidade, estar de acordo com os padrôes urbanísticos e ambientais exigidos em lei.

Portanto, é tarefa de alta complexidade, eminentemente extrajudicial no princípio - podendo redundar em ajuizamento de açóes -, passa pela esfera de escuta e interlocução entre as partes envolvidas, pela tomada de informaçōes por meio da realização de audiências públicas - espaço de fala de todos -, pela exigência de tomadas de providencia pelo poder público. Muito além de exigir a efetivaçáo do direito à moradia, do cumprimento da função social da propriedade, a Defensoria Pública da União é ativa participante da formação do espaço público.

\subsection{Regularizaçáo Fundiária de Imóveis da Uniáo}

Os Programas Habitacionais jamais superaram o déficit de moradias para as classes com menor poder aquisitivo, que dificilmente conseguem arcar com os elevados custos da moradia no país. Deste modo, a ocupação ilegal para fins de moradia e a construçáo em locais inadequados é uma realidade.

\footnotetext{
16 https://www1.folha.uol.com.br/cotidiano/2018/05/de-luxo-modernista-a-ocupacao-precaria-a-historiade-mais-de-meio-seculo-do-predio-que-desabou-em-sao-paulo.shtml?origin=folha

17 Registra-se que na fase extrajudicial a atuação se deu de forma conjunta, no âmbito da DPU, por meio da atuação do $2^{\circ}$ Ofício Regional de Direitos Humanos e do Grupo de Trabalho em Defesa dos Direitos da População em situação de Rua de São Paulo.

18 ACP 5011970-90.2018.4.03.6100, 25ª Vara Cível Federal da Subseção Judiciária do Estado de São Paulo.
} 
É comum nos grandes centros a ocupação de prédios e terrenos abandonos, já nas áreas mais afastadas do centro a ocupaçáo normalmente ocorre em áreas protegidas ambientalmente.

A segregaçáo social gerou na sociedade contemporânea um processo antagônico, isto porque o cidadão vulnerável está à margem de direitos básicos (moradia, acesso à rede de esgoto, saúde, educaçáo etc), sujeito a todas as injustiças ambientais, lhe sobra residir em favela sem saneamento básico, em encostas de morros, perto de mananciais poluídos, porém é este cidadão sem informação que vai colaborar no processo de degradação ambiental. Por conseguinte, é causador e vítima.

Por sua vez, é diretriz da política urbana, estatuída pela Lei n. 10.257/01 - Estatuto das Cidades -, em seu artigo $2^{\circ}$, XIV, a regularização fundiária e a urbanização de áreas ocupadas por população de baixa renda, mediante o estabelecimento de normas especiais de urbanização, uso e ocupação do solo e edificação, devendo ser considerada a situação socioeconômica da população e as normas ambientais.

Deste modo, com o fito de assegurar o cumprimento da função social da propriedade e da cidade, os entes da federação viram-se obrigados ao reconhecimento legal e jurídico da moradia e da posse daqueles que vivem em assentamentos irregulares ou informais. Nessa senda foi editada a Lei $n$. 13.465/2017, que dispóe sobre a regularização fundiária urbana e rural, revogando o capítulo III da Lei n. 11.977/2009 que estabelecia normas sobre o tema.

A nova lei de regularização fundiária urbana - Reurb - foi editada em meio a diversas polêmicas, se de um lado há os que a defendem sob o viés de que trouxe regras facilitadoras da regularização, de outro lado ela já é objeto de três ADIs (5883, 5787 e 5771).

A Regularização pode ser dividida em Reurb de Interesse Específico (Reurb-E) e Reurb de Interesse Social (Reurb-S), o que diferencia as modalidades é a constituição dos ocupantes, no caso da de interesse social a populaçáo de baixa renda assim declarada em ato do Poder Executivo municipal, estando estes isentos de custas e emolumentos de diversos atos registrais.

É de se dizer que a Reurb-S engloba também conjuntos habitacionais ou condomínios de interesse social construídos pelo poder público, diretamente ou por meio da administração pública indireta.

Registra-se que a Reurb não visa apenas legalizar a posse dos ocupantes, mas é um conjunto de normas e procedimentos que abrange medidas jurídicas, ambientais, urbanísticas e sociais. Especificamente na Reurb-S caberá ao poder público competente implementar a infraestrutura essencial, os equipamentos comunitários e as melhorias habitacionais previstos nos projetos de regularização, assim como arcar com os ônus de sua manutenção.

Não se pode deixar de mencionar que o principal objetivo da política patrimonial é a monetarização do patrimônio público por meio da venda dos imóveis, conforme se observa da Lei n. 13.240/2015 e da Lei n. 13.465/2017. Todavia a lei editada em 2017, ao prever expressamente a possibilidade de regularização fundiária de bens pertencentes à União, traz mecanismo que facilitam a regularização como a desnecessidade de desafetação do bem público e a simplificação da titulação da propriedade para as pessoas físicas de baixa 
renda que, por qualquer título, utilizem regularmente imóvel da União ou provenientes de entidades federais extintas, para fins de moradia até 22 de dezembro de $2016 .{ }^{19}$

Importante inovação da nova legislação foi a inclusão da Defensoria Pública como legitimada para requerer a Reurb-S, podendo, para tal, promover todos os atos necessários à regularização fundiária, inclusive requerer os atos de registro.

A atuação da Defensoria Pública se dá de forma conjunta e articulada com os demais entes públicos responsáveis pela regularização fundiária de interesse social. Como a Reurb abrange, além de medidas jurídicas, medidas ambientais, urbanísticas e sociais diversas esferas governamentais devem necessariamente se envolver no projeto. No caso de imóveis pertencentes à União a Secretaria de Patrimônio Público (SPU) - caso não tenha havido transferência da área pública federal ocupada aos Estados, aos Municípios e ao Distrito Federal para que estes promovam a Reurb - é o órgáo a ser acionado para fins de promoção da regularizaçãa.

Vale aqui anotar que o simples requerimento da Reurb-S pelos legitimados, junto ao órgão competente, já produz efeitos imediatos, como elucida Mario do Carmo Ricalde ocorre a estabilização da posse até decisão final:

O requerimento de instauraçáo de Reurb ou, na forma de regulamento, a manifestação de interesse nesse sentido por parte de qualquer dos legitimados garantem perante o poder público aos ocupantes dos núcleos urbanos informais situados em áreas públicas a serem regularizados a permanência em suas respectivas unidades imobiliárias, preservando-se as situaçóes de fato já existentes, até o eventual arquivamento definitivo do procedimento. ${ }^{20}$

Em havendo concordância da União com a regularização a titulação para a população de baixa renda pode se dar por diversos instrumentos como a concessão de direito real de uso - CDRU, concessão de uso especial para fins de moradia - CUEM, doação, legitimação fundiária, direito de superfície e aforamento.

A regularização fundiária, além de garantira a segurança jurídica da posse, é importante instrumento de inserção social, e como tal em ocorrendo omissão do poder público em efetivá-la a atuação da Defensoria Pública poderá se dar por meio de ingresso de açôes judiciais.

\footnotetext{
19 Lei n. 13.465/2107:
}

Art. 71. Para fins da Reurb, ficam dispensadas a desafetação e as exigências previstas no inciso I do caput do art. 17 da Lei no 8.666, de 21 de junho de 1993.

Art. 86. As pessoas físicas de baixa renda que, por qualquer título, utilizem regularmente imóvel da União, inclusive imóveis provenientes de entidades federais extintas, para fins de moradia até 22 de dezembro de 2016, e que sejam isentas do pagamento de qualquer valor pela utilização, na forma da legislaçáo patrimonial e dos cadastros da Secretaria do Patrimônio da Uniáo (SPU), poderão requerer diretamente ao oficial de registro de imóveis, mediante apresentação da Certidão de Autorização de Transferência (CAT) expedida pela SPU, a transferência gratuita da propriedade do imóvel, desde que preencham os requisitos previstos no $\$ 5^{\circ}$ do art. 31 da Lei no 9.636, de 15 de maio de 1998.

20 RICALDE, Mario do Carmo. Regularizaçáo Fundiária Rural e Urbana: impactos da Lei no 13.465/17. $1^{\text {a }}$ ed. Campo Grande: Contemplar, 2018, p 138. 
Relativamente ao que se discute temos a exitosa atuação da Defensoria Pública da União em Santa Catarina, que por meio do Defensor Regional de Direitos Humanos postulou a regularização fundiária do bairro Pontal, localizado no Município de Palhoça/SC. Visando impulsionar as tratativas entre os órgãos envolvidos utilizou-se, para composição do conflito, o procedimento da reclamação pré-processual $(\mathrm{RPP})^{21}$, estando o processo de regularização em fase de andamento. ${ }^{22}$

Todavia, é de se reconhecer que a maior parte dos pedidos de regularização fundiária se dá quando já em andamento açóes possessórias ou ações civis públicas contra os ocupantes, tal qual ocorreu no requerimento de regularização fundiária formulado pela Defensoria Pública da União e Ministério Público Federal em favor dos ocupantes de terreno de marinha, localizado em área conhecida como Portinho, no Município de Joinville/SC. ${ }^{23}$

A atuação da Defensoria Pública, portanto, poderá se dar na via administrativa, como legitimado para requerer a Reurb-S, e na via judicial para fins de garantir o direito de uso dos possuidores do imóvel.

A Defensoria Pública instituição de defesa dos vulneráveis precisa assumir o protagonismo que a nova lei de regularização fundiária lhe atribuiu, atuar requerendo a regularização antes de instaurados os conflitos judiciais e, em sendo refratária a administração pública ao requerimento, utilizar-se para deflagrar o processo de estratagemas como a reclamação pré-processual.

\section{CONSIDERAÇÓES FINAIS}

A clivagem social brasileira tem profunda ligação com a constituição do espaço urbano, se por um lado o mercado imobiliário precificou a terra criando exclusão e enormes bolsóes de informalidade, de outro o mercado de trabalho segmentado territorialmente dispersou a mão de obra operária.

Os programas habitacionais, apesar de garantida da moradia, não foram capazes de reduzir a desigualdade social, ao contrário, contribuíram para a expansão do território urbano, com a segregaçáo dos menos favorecidos em periferias nem sempre guarnecidas de equipamentos públicos.

Faz-se necessário um novo projeto de urbanização, que seja capaz de incluir nos espaços públicos todos os estratos sociais, que faça ruir a exclusividade territorial, e importante forma de alcançá-lo é por meio de projetos habitacionais.

21 Resolução n. 15, de 23 de fevereiro de 2017, do Tribunal Regional Federal da 4a Região.

22 Reclamação pré-processual n. 5002462-91.2018.4.04.7200/SC, CEJUSCON de Florianópolis

23 https://www.dpu.def.br/noticias-santa-catarina/158-noticias-sc-slideshow/49748-dpu-requerregularizacao-fundiaria-da-comunidade-do-portinho-em-joinville 
Em todo país existem imóveis públicos desocupados ou ocupados irregularmente, situados em áreas privilegiadas, capazes de fomentar a inclusáo social ao garantir que os antes excluídos tenham acesso as mesmas possibilidades econômicas e culturais de poucos privilegiados.

Não apenas isto, mas os imóveis públicos têm o dever de cumprir sua função socioambiental, estando tal dever associado a obrigação de redução das desigualdades territoriais e sociais, promoção da justiça social, com a garantia de moradia digna e não se pautando exclusivamente na função arrecadadora do patrimônio.

Para cumprir a importante tarefa de agente de redução das desigualdades sociais a Defensoria Pública tem que se lançar na atuação preventiva dos conflitos, em colaboração com outras instituiçóes (inclusive formalizando parcerias para utilizar serviços de especialistas que náo tenha em seus quadros) e sociedade civil no processo de mobilizaçáo social e sensibilizaçáo da administraçáo pública para que esta concretize o direito à moradia aos vulneráveis. Ademais, em consolidada as ocupaçóes pela população de baixa renda, sem que se espere o ajuizamento de açóes possessórias ou ações civis públicas, deveria a Defensoria Pública ser a instituiçáo que toma a frente dos requerimentos de Reurb-S, mostrando-se o procedimento da reclamação pré-processual de grande utilidade para deflagrar o processo.

A incumbência da Defensoria Pública de participar do planejamento urbano dos espaços públicos, por meio da defesa da moradia digna, da exigência do cumprimento da função social da propriedade, da inserção dos excluídos no processo decisório das cidades, traz inúmeros desafios, mas a instituição não pode fugir da missão que lhe foi atribuída constitucionalmente ao ser alçada a instrumento do regime democrático, é seu dever participar da restauraçáo da solidariedade e do senso de comunidade indispensáveis a cidadania democrática que se restabelecerá, dentre outros, com o fim da segmentaçáo espacial calcada na classe social.

\section{REFERÊNCIAS}

BRASIL. Constituição (1988). Constituição da República Federativa do Brasil. Brasília: Senado, 1988.

Decreto n. 1.749, de 26 de junho de 1937. Aprova novo regulamento para a aquisiçáo de prédios destinados a moradia dos associados e a séde dos Institutos, e Caixas de Aposentadorias e Pensóes. Rio de Janeiro: Presidência da República, 1937.

Decreto-Lei n. 9.218, de $1^{\circ}$ de maio de 1946. Autoriza a instituiçáo da "Fundaçáo da Casa Popular”. Rio de Janeiro: Presidência da República, 1946.

Decreto-Lei n. 9.777, de 6 de setembro de 1946. Estabelece bases financeiras para a "Fundaçáo da Casa Popular" e dá outras providências. Rio de Janeiro: Presidência da República, 1946. 
Lei n. 601, de 18 de setembro de 1850.

Dispóe sobre as terras devolutas do Império. Rio de Janeiro, 1850.

. Lei n. 4.380, de 21 de agosto de 1964. Institui a correçáo monetária nos contratos imobiliários de interêsse social, o sistema financeiro para aquisiçáo da casa própria, cria o Banco Nacional da Habitaçáo (BNH), e Sociedades de Crédito Imobiliário, as Letras Imobiliárias, o Serviço Federal de Habitação e Urbanismo e dá outras providências. Brasília: Senado, 1946.

. Lei n. 10.257, de 10 de julho de 2001. Regulamenta os arts. 182 e 183 da Constituiçáo Federal, estabelece diretrizes gerais da política urbana e dá outras providências. Brasília: Senado, 2001

.Lei n. 13.240, de 30 de dezembro de 2015. Dispóe sobre a administraçáo, a alienaçáo, a transferência de gestáo de imóveis da União e seu uso para a constituiçáo de fundos; altera a Lei no 9.636, de 15 de maio de 1998, e os Decretos-Lei nos 3.438 , de 17 de julho de 1941, 9.760, de 5 de setembro de 1946, 271, de 28 de fevereiro de 1967, e 2.398, de 21 de dezembro de 1987; e revoga dispositivo da Lei no 13.139, de 26 de junho de 2015. Brasília: Senado, 2015.

. Lei n. 13.465, de 11 de julho de 2017. Dispóe sobre a regularizaçáo fundiária rural e urbana, sobre a liquidaçáo de créditos concedidos aos assentados da reforma agrária e sobre a regularizaçáo fundiária no âmbito da Amazônia Legal; institui mecanismos para aprimorar a eficiência dos procedimentos de alienação de imóveis da União; altera as Leis $\mathrm{n}^{\text {os }} 8.629$, de 25 de fevereiro de 1993,13.001, de 20 de junho de $2014,11.952$, de 25 de junho de 2009, 13.340, de 28 de setembro de 2016, 8.666, de 21 de junho de 1993, 6.015, de 31 de dezembro de 1973, 12.512, de 14 de outubro de 2011, 10.406, de 10 de janeiro de 2002 (Código Civil), 13.105, de 16 de março de 2015 (Código de Processo Civil), 11.977, de 7 de julho de 2009, 9.514, de 20 de novembro de 1997, 11.124, de 16 de junho de 2005, 6.766, de 19 de dezembro de 1979, 10.257, de 10 de julho de 2001, 12.651, de 25 de maio de 2012, 13.240, de 30 de dezembro de 2015, 9.636, de 15 de maio de 1998, 8.036, de 11 de maio de 1990, 13.139, de 26 de junho de 2015, 11.483, de 31 de maio de 2007, e a 12.712, de 30 de agosto de 2012, a Medida Provisória no 2.220, de 4 de setembro de 2001, e os Decretos-Leis n⿳⺈ 2.398, de 21 de dezembro de 1987, 1.876, de 15 de julho de 1981, 9.760, de 5 de setembro de 1946, e3.365, de 21 de junho de 1941; revoga dispositivos da Lei Complementar no 76, de 6 de julho de 1993, e da Lei no13.347, de 10 de outubro de 2016; e dá outras providências. Diário Oficial da União, Brasília, 12 jul. 2017. Retificado em 6 de jul. 2017 e publicado texto consolidado no DOU de 8 set. 2017.

. Medida Provisória 2.220, de 4 de setembro de 2000. Dispóe sobre a concessáo de uso especial de que trata o $\$ 1^{\circ}$ do art. 183 da Constituição, cria o Conselho Nacional de Desenvolvimento Urbano - CNDU e dá outras providências. Diário Oficial da União, Brasília, 5 set. 2001.

. Ministério do Planejamento, Desenvolvimento e Gestão. Nota à Imprensa sobre Imóveis da Uniáo. Disponível em: http://www.planejamento.gov.br/noticias/nota -a-imprensa-7, publicado em 02/05/2018. Acesso em: 31 out. 2018. 
Resolução n. 2458 do Conselho Monetário Nacional, de 18 de dezembro de 1997. Dispóe sobre a utilizaçáo de alienação fiduciária de coisa imóvel, nos termos da Lei no 9.514, de 20.11.97, em contratos de financiamento habitacional de que trata o Regulamento anexo à Resoluçáo no 2.458, de 18.12.97. Brasília: Banco Central do Brasil, 1998

Supremo Tribunal Federal. ADI 5771, Rel. Ministro Luis Fux.

. Supremo Tribunal Federal. ADI 5787, Rel. Ministro Luis Fux.

. Supremo Tribunal Federal. ADI 5883, Rel. Ministro Luis Fux.

Tribunal de Contas da União, Processo TC 025.715/2017-8, Acórdão

1273/2018, Relator Ministro Vital do Rêgo, Julgado em 06/06/2018.

. Tribunal Regional Federal da 4a Região, Resoluçáo n. 15, de 23 de fevereiro de 2017. Regulamenta o procedimento da relação pré-processual e o da homologação de acordo extrajudicial dela decorrente. Diário Eletrônico Administrativo de 7 de mar. 2017.

Tribunal Federal da 5a Regiấo, ACP 2004.84.00.008808-7/RN, Relator Desembargador Federal Emiliano Zapata Leitão, DJe 16/09/2010.

Justiça Federal de Santa Catarina, CEJUSCON de Florianópolis, Reclamação pré-processual n. 5002462-91.2018.4.04.7200/SC.

Justiça Federal de São Paulo, 25a Vara Cível Federal da Subseção Judiciária do Estado de São Paulo, ACP 5011970-90.2018.4.03.6100.

COSTA, Duane Brasil e AZEVEDO, Uly Castro de. Das Senzalas às Favelas: Por onde vive a populaçáa negra brasileira. Disponível em: http://www.fvj.br/revista/wp-content/uploads/2016/07/Socializando_2016_12.pdf. Acesso em: 30 out. 2018.

INSTITUTO BRASILEIRO DE GEOGRAFIA E ESTATÍSTICA - IBGE. Séries Históricas e Estatísticas. Taxa de Urbanização. Disponível em: https://seriesestatisticas. ibge.gov.br/series.aspx?vcodigo=POP122. Acesso em: 30 out. 2018.

FIGUEIREDO, Guilherme José Purvin de. A Propriedade no Direito Ambiental. 3. ed. rev. atual e ampl. São Paulo: Editora Revista dos Tribunais, 2008.

FIX, Mariana. Financeirização e transformaçóes recentes no circuito imobiliário no Brasil. (Tese de Doutorado em Desenvolvimento Econômico. IE-Unicamp, Campinas, 2011). Universidade Estatual de Campinas, Instituto de Economia, Campinas, 2011.

NOGUEIRA, Ligia e SOUZA, Felipe. De luxo modernista à ocupaçáo precária: a história de mais de meio século do prédio que desabou em São Paulo. Folha de São Paulo, São Paulo, $1^{\circ}$ de maio de 2018. Disponível em: https://www1.folha.uol.com.br/cotidiano/2018/05/de-luxo-modernista-a-ocupacao-precaria-a-historia-de-mais-de-meio-seculo-do-predio-que-desabou-em-sao-paulo.shtml?origin=folha. Acesso em: 5 dez. 2019. 
RICALDE, Mario do Carmo. Regularização Fundiária Rural e Urbana: impactos da Lei no 13.465/17. $1^{\text {a }}$ ed. Campo Grande: Contemplar, 2018.

ROLNIK, Raquel. Guerra dos Lugares: A colonização da terra e da moradia na era das finanças. 1ª ed. São Paulo: Boitempo, 2015.

SANTOS, Milton. A Urbanizaçáa Brasileira. 5. ed, 4 reimpr. São Paulo: Editora da Universidade de São Paulo, 2018.

SOUZA, Leda Maria. Análise Comparativa Das Políticas Habitacionais Nos Governos Fernando Henrique Cardoso E Luiz Inácio Lula da Silva. 2005. Dissertação (Mestrado Profissionalizando em Gestão de Políticas Públicas) - Universidade do Vale do Itajaí - UNIVALI, Itajaí, 2005. 